\title{
The Impact of Zoning System to Student Achievement and School Innovation
}

\author{
Juwita Ismabela \\ Department of Education Management \\ Universitas Negeri Surabaya \\ Surabaya, Indonesia \\ juwita.18013@mhs.unesa.ac.id
}

\begin{abstract}
This article aims to reflect and explain the impact that may accur a result of the enactment of zoning in the education system. This study uses literature study and survey research method. The recruitment of new students, mostly without using the value of the test results the appear paradigm learners and parent that do not need to study seriously because test scores are not used in entering a new school level. Another problem appears also that schools would be reluctant to innnovate to compete with other school, because of thr presence of this zoning systems of thr schools will be easy to get the students without having to do marketing or innovation program. Solutions for people to receive good the policy is to disseminate clearly and will continue monitoring the impelmentation of policies and revise as needed in the field.
\end{abstract}

Keywords—zoning; student achievement; innivation

\section{INTRODUCTION}

The quality of human resources into factors that determine the progress of a nation. Some countries that do not have abundant natural resourcer can be a developed country because it has a superior human resources for this matter it needs good personel management. According to flippo [1] personel management is planning, organizing, directing, and controlling of procurement development, compensation, integration, maintance, and termination of employees, with the intention of realization of objectives of the company, individuals, employees, and the community. Education is a basic human to explore new knowledge to be able to be better. Through education, to human ability to rise and human qualities and have also. The term "education" refers to the board functon of preserving and inproving the life of the group through bringing new members into its shared concerns. Education is thus a far broader process thah that which occurs in schools. It is an essentials social activity by which communication continue to exist in complex communication this function is specialized and institutionalized in formal educatoin, but there is always the education outside the school with wich the formal prosess in related.

Education is a tool to train develop, and bring the potential of learners in terms of academic and non-academic in order to manifest the fuction and purpose of national education. The word educations is sometimes used in a broad sense and narrow sense [2]. In broad terms educational is all experience, it can be said also that life is education or education is life.
Implementation of education in Indonesia is not much of a problem, one of which is equitable quality of education. In an effort to resolve the issue of zoning policy applies for admission of new students. The Ministry of Education An Culture Is Ussed The Regulation Of The Minister of Education And Culture number 14 of 2018 or Admission of Students New in kindergarten, elementary school, junior high school, senior high school, high school, vocational school. The purpose of goverments to revitalize the implementation of the admission of new students thath lasted more objective accountable, transparant, non discriminatory, ad fairness it also update some of the provisions governing the procedures of admission of students new ranging from requirements, selestion, zoning system, including setting the number students in the study groups and the number of classrooms in the educational unit.

Some time past often appear complaints about the zone system in the recruitment of new students. Complaints arise not only from the school but also on the part of prospective student and parents, as happened in the first secondary school level. Learners who want schools in education institutions of their choice be realized due to the policy of zoning system. Recruitment zoning system allows new problems because the value of national test result are not used in the new school entrance, high or low value just the same origin witah a raduis house near the school, the value of the test results apply to track achevements but probably only $20 \%$ so there is a paradigm of the students and parents that do not need to study seriously because test scores are not used in entering a new school level. In addition to these problem there are also problems that the school would be reluctant to innovate to compete with other school, because the presence of this zoning sytems of the schools will be easy to get the students without having to do marketing or innovation because the program is difinitely going to get a new learner. According to because with this zoning systems of the school will be easy to get the students without having tp do marketing or innovation because the program is definitely going to get a learner. Innovation is more than just a change, despite all of the innovations involves changes based on the theory if no innovation there will be no changes at the school.

\section{METHOD}

In this paper the method of literrature study. Library studies occupy a very important position in research. Literature studies 
are theoretical studies, references and other scientific literature relating to culture, values and norms taht develop in the social situation under study [3]. Concucting research means trying to find a solution to a problem that is the done in scientific ways, one of them is by literature. Library study is technique of collecting data and information by examining written sources such as scientific journals, reference books, literature, encyclopedias, scientific writings, as well as other reliable sources both in a digital format that is relevant and related to the object being syudied. By examining reference books we can solve problem based on theories taht have been tested for truth and are generally recognized. In addition we can also examine provious studies related to objects taht are being discrussed through easily accessible scientific journals. Zoning is new policy that research is still minimal and theories are still little, so as to support this paper the authors used survey method. Survey is a method that uses questions to measure the phenomenon of interest is another essential part of survey research. Especially important when trying to measure phenomena that cannot be directly observed, such us attitudes, feelings, and cognitions [4]. In this paper it uses the study of goverment policies, theories, and facts that are happening in the field and concuct surveys in the field to find out about the response of consumer education about zoning. .

\section{RESULTS AND DisCUSSION}

\section{A. The Response of Educational Consumers After the Dissemination of the Implementation of Zoning System Policies}

Asri Ulfah [5] expalined that "acceptance of students in an educational institution is very important, because with hte acceptance of professionally managed students, they will benefit the school in the field of registration which will later becamo students in the institution the education". Acceptance of new students according to Asri Ulfah [5] "is one of the management activities of students that is very important, because if no students are accepted, then there is nothing in the school that must be handled or regulated". Acceptance of new students is something that need to be determined quickly and preciesly. Admission of new students is being implemented a new system of zoning. Zoning is a system of students acceptance where $80 \%$ of students admissions use the distance of the house to the nearest school, $15 \%$ use the path of achievement and $5 \%$ based on the transfer of duties of parents. based on the reality in the field, there many education consumers who compalin that this zoning system policy is implemented because this is new and people are not familiar with the policy. Based on the suvery results $56 \%$ of female respondents and $44 \%$ of male respondents who filled out the survey coulumn provided. This survey takes respondents from junior high school graduates in 2019, and is enrolling themeselves $\mathrm{n}$ high school. This is adjusted to the application of the acceptane of the new students zoning system. As many as $73.4 \%$ of respondents answered disagree with the acceptance of the new students zoning system, then $26.6 \%$ answered agreed. The reason for the rejection of the zoning system is they could not enter the expected school of $46.4 \%$. the school facilities were not evenly distributed $11.3 \%$ the $9.2 \%$ reasoned with a high exam score $13.3 \%$, removing the predicate of favorite school $13 \%$, and school distance close to home $6.4 \%$.. Even though the policy is to make it easier for prospective students to acces schools, a zoning system is impelmented. This arrangement is expected to make the acceptance process take place in an objective, accountable, tranparent, and without discrimination to improve access to education services. In article 15 of Permendikbud No. 17 of 2017 , it is expalined that by implementing a zoning system, schools organized by local goverments must accept prospective students who life in the radius of the closest zone of the school at least 90 percent of the total number of student received.the domicile of prospective students is based on the address on the family card that is issued no later than six months before the implementation od PPDB. In the state of Nigeria the zoning system could lead to teacher inability, lack of professional support and poor teaching in secondary schools. This is more reason why secondary school zoning schemes are assessed in term of the administration is scces and economic pedagogical politics in the State Adamawa[6]. Economis presure on the education system results in failures in student achievement tests, enrollment participation and test repetition rates. The potuguese languange cabter of the education cluster has failed to acheive the objectives of the education system [7]. Starting from the solution so that the community can accept the policy well, it is to socialize explicity and continue to monitor th implementation of the policy and revise it according to the needs in the field.

\section{B. Prediction of Student Achievement Due to Recruitment of} New Students using Zoning System Policies without Considering that Value of the Test Results

The implementation of the zonong system to register at the nearest school, can no longger apply to schools that are far away but have a favorite status. So in the future there will be no more favorite and not favorite school titles. All school will become favorite school and produce quality young generation. The recruitment of the zoning system can also create new problems because the value of the national exam results is not used in entering new schools, high or low scores are the same as the home radius of the school close, the test results are valid for the achievement path, but it is likely only $20 \%$ so that a paradigm of students and parents emerges that think that there is no need to study seriously because test scores are not used in entering the new school level. Whereas in education taht occurs abroad Sigrid Blomeke, Rolf Vegar Olsen and Ute Suhl [8] explain that several studies have astablised a relationship between the size of teaching quality and student achievement, student motivation, or other school. The debate that has taken place in the economic education literature is whether increasing educational resourches can move the needle on student achievement. Make researchers not confident in claiming a definite causal relationship between education in student expenses and achievements. Educational resourches and student achievements that develop from time to time are not far from funding. Educational funding is expected [9]. To provide additional resourches to disadvantaged school districts to close academic achievement gaps, but their efforts are subject to criticism from skeptics who believe that extra economic pressure on the education system can affect student achievement. 


\section{School Innovation After Zoning System Policy was Implemented}

In the field of education, innovation usually arises from the anxiety of certain parties about the impelmentation of education. For example, teacher anxiety about the implementation of teaching and learning processes taht are considered to be unsuccessful, the anxiety of the education administrator about performance, or perhaps concerns about the performance and results of the education system. The unrest eventually formed problems taht demanded immediate handling. This effort to solve problems emerged new ideas and ideas is an innovation. Thus, we can say that the implementation exists because of a perceived problem: it is almost impossible for innovation to emerge without a perceived problem. From the various opinions above it can be concluded that education innovation is something new in certain social situations that are used to answer or solve a problem. Viewed from the form or form "something new" can be in the form ideas, ideas, objects or maybe actions. Innovative changes in schools reflect the development and needs of society [10], they define innovation as new concepts, method, and product. While acording to John Turner [11] for effective school learning includes formative ecaluation, direct instruction, tacher clarity, and good strategies. Based on these two things, it can be explained that with new concepts and methods to create new products. Based on the theory above, the implementation of the zoning system will emerge new problems, namely schools will be reluctant to innovate in competing with other schools, because with the zoning system schools will be easy to get students without having to do marketing or program innovation because it will certainly get new students. But because education is always experincing food development needs innovation. According to the Norwegian School of Business Study, it defines innovative characteristics as associative orientation, ambition, originality, flexibility, and motivation [12]. Dyer Gregersen and Cristensen also identified five skills for innovation: getting along, asking, observe, experimenting, and worj. Based on this theory, the school still needs to innovate to keep developing. This is an accordance with the theory John Turner [13] which explains that students and learning are the drivers because it lies in the common goal of seeking continous improvement as a school as an institution is a collection of strengeths, weakness, opportunities, and threats (which are excanged depending on the mindset and one's location) and Uchendu's theory [14] describes innovation as a process in which new programs or practices are implemented or injected into system operations to replace the old or ineffective ones. School as communities have the power in their capacity to be providers of skills and atributes, and as providers of academic understanding(including certification.

\section{CONCLUSION}

The purpose of implementing this zoning system is indeed able to everride equitable quality of education, but recruitment which cloud lead to new problems because the value of national examination results are not used to enter a new school, high or low value the same as the origin of the reach of home and school near, the test result scores are valid for the track of achievement but only $15 \%$ snd $5 \%$ may be for reasons of moving parents, so that it appears paradigm learners and parents who think there is no need to seriously study because test scores are not used in entering new school level. In addition to these there are also problems. The schools will be reluctant to innovate to compete with other schools, because with zoning systems of the school will be easy to get the students without having to do marketing or innovation because the program is difinitely going to get a new learner. But besidse that innovation is still needed to improve the quality of graduate school or the quality that education in Indonesia also increased. Based on some of the above it is necessary to study in greater depth in this zoning system policy implementation so that Indonesian education is more advanced.

\section{REFERENCES}

[1] Hasibuan M, "Manajemen personalia dan sumber daya manusia", Jakarta: Bumi Aksara, 2013

[2] Ruppert C. Lodge, "Phtlosophy of education", New York: Harper and Brothers, 2015

[3] Sugiyono, Metode penelitian kuantitatif, kualitatif dan R\&D, Badung: Alfabeta, 2014

[4] Ronald C. Martella, J. Robald Nelson, Robert L Morgan, and Nancy E. Marchand- Martella, "Understanding and interpreting educational research, Guilford Press, 2013.

[5] Ulfah Asri dkk., Efektifitas penerimaan peserta didik baru (PPDB) melalui sistem penerimaan peserta didik onlline, 2016

[6] Permendikbud Nomor 17 Tahun 2017

[7] Badau Kabiru M., "Assessing the success of school cluster zoning system in senior secondary schools of adamawa state nigeria", Nigeria, 2015

[8] Blomeke Sigrid, Olsen Rolf V., and Suh Ute, "Relation of student achievement to the quality of their teachers and instructional quality", Oslo Norwey. 2016

[9] Gigliotti Phillip and Sorensen Lucy C., "Educational resourches and student achievement: evidance from aave harmless provivion in new york", New York, 2018

[10] Ellis and Bond, "Innovation, inovators and school", 2016

[11] Turner John, "Innovation making model”, Norwegia, 2017

[12] Turner John, "Innovators and School”, Nowergia, 2017

[13] Gregersen Dyer and Christensen, "Norwegian business school study", Norwegia, 2013

[14] Uchendu, "Innovation and School, 2015 